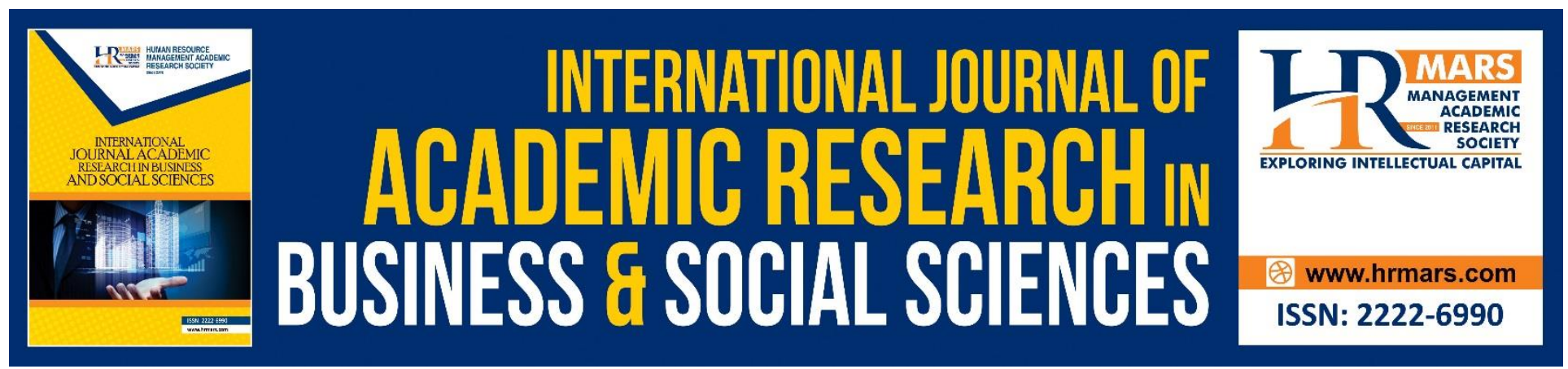

\title{
The Moderating Effect of Managerial of Innovation on Leadership Styles and Job Satisfaction in Jordanian University Private
}

Hafsa Yahea Aljamal, Najihah Abd Wahid

To Link this Article: http://dx.doi.org/10.6007/IJARBSS/v10-i7/7395

DOI:10.6007/IJARBSS/v10-i7/7395

Received: 19 April 2020, Revised: 27 May 2020, Accepted: 08 June 2020

Published Online: 23 July 2020

In-Text Citation: (Aljamal \& Wahid, 2020)

To Cite this Article: Aljamal, H. Y., \& Wahid, N. A. (2020). The Moderating Effect of Managerial of Innovation on Leadership Styles and Job Satisfaction in Jordanian University Private. International Journal of Academic Research in Business and Social Sciences, 10(7), 42-51.

Copyright: (C) 2020 The Author(s)

Published by Human Resource Management Academic Research Society (www.hrmars.com)

This article is published under the Creative Commons Attribution (CC BY 4.0) license. Anyone may reproduce, distribute, translate and create derivative works of this article (for both commercial and non-commercial purposes), subject to full attribution to the original publication and authors. The full terms of this license may be seen

at: http://creativecommons.org/licences/by/4.0/legalcode

Vol. 10, No. 7, 2020, Pg. 42 - 51

http://hrmars.com/index.php/pages/detail/IJARBSS

JOURNAL HOMEPAGE

Full Terms \& Conditions of access and use can be found at http://hrmars.com/index.php/pages/detail/publication-ethics 


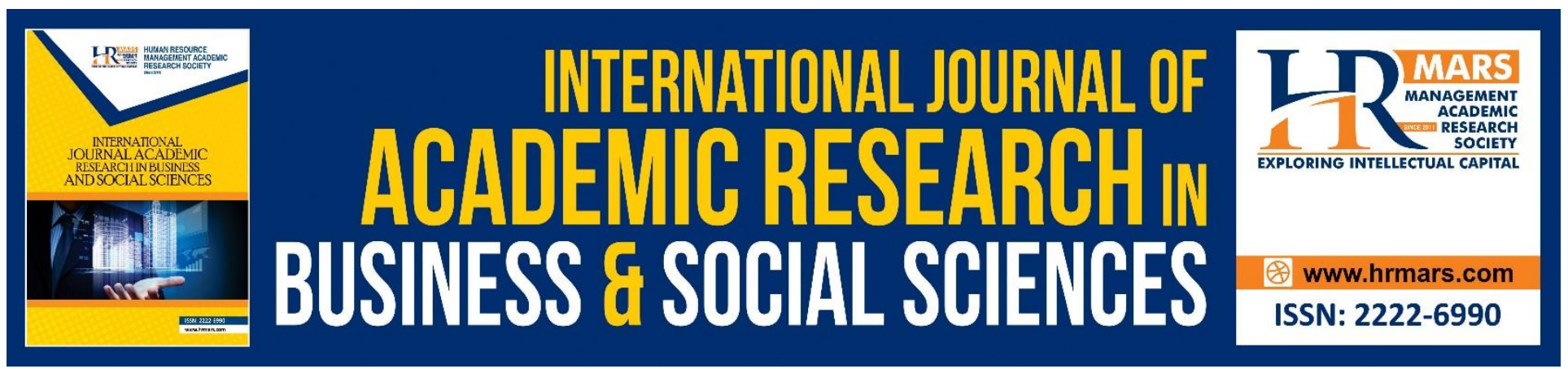

\title{
The Moderating Effect of Managerial of Innovation on Leadership Styles and Job Satisfaction in Jordanian University Private
}

\author{
Hafsa Yahea Aljamal, Najihah Abd Wahid \\ Faculty of Contemporary Islamic Studies, Universiti Sultan Zainal Abidin, \\ 21030 Kuala Nerus, Terengganu \\ Email: Hafsa.aljamal@yahoo.com, anajihah@unisza.edu.my
}

\begin{abstract}
This study aimed to reveal the relationship between leadership styles of faculty deans in private universities with the job satisfaction of faculty members in Jordan. Two types of leadership styles were chosen, namely the autocratic leadership style and the free leadership style in the presence of a Moderating variable, which is the managerial of innovation of faculties deans in those universities. In those universities, the questionnaire was also distributed to the study sample in a random and systematic way, which consisted of (345) members. The study concluded that there is a negative relationship between the autocratic leadership style and the free leadership style and job satisfaction of the faculty members in the presence of a Moderating variable (managerial of innovation).
\end{abstract}

Keywords: Leadership, Job Satisfaction, Autocratic Leadership Style, Free Leadership Style, Managerial of Innovation.

\section{Introduction}

The progress made in the fields of scientific research has contributed to the progress and enrichment of human awareness in general, which is controlling the various natural and human phenomena in the various fields and the diversity of specialization. Hence, the educational institutions have been faced with many difficulties and challenges in how to cope with them and how to adapt to them (Brayah, 2016). All of these variables added great burdens on educational institutions in finding modern and creative methods, rejecting sterile traditional procedures by finding innovative people, and providing appropriate means that help to innovate rapid administrative methods and solutions, leading to achieving distinctive institutional performance. Although there are many factors inside and outside the educational institution that affect the level of job performance, there are many studies that indicate that leadership styles within the educational department play an important role in creating the appropriate administrative environment that enables the individual to be motivated to do more giving This achieves good levels of performance (Zakaria, 2017). 
It relies on the performance of the faculty members in any academic institution in performing the educational tasks entrusted to them at the level of performance competencies and the competencies of the guarantor to achieve the goals and purposes that it seeks to achieve. Just as it relies on the educational leadership styles adopted by the deans of faculties in Jordanian universities in their dealings with their faculty members. This contributes to unleashing their energies and innovation and achieving job satisfaction for them, which contributes to improving the educational process, which is thus reflected on students (Arabiyat, 2012).

Where job satisfaction is considered to be the primary concern in all strategies, as it is the bridge that achieves efficiency, as research and study is shown by researchers in particular and educational leaders in general for various reasons, so what the individual currently pleases may not satisfy him in the future and vice versa.

The university is a unique institution with a complex structure with distinct goals, in which officials undertake tasks of a special scientific nature, and they pursue multiple paths in these universities (AlMikhlafi, 2009).

In order to achieve job satisfaction for them, we must here be certain of the great role that decisionmakers in these universities, especially the deans of faculties, will have on them, because of their effectiveness in achieving job satisfaction for their faculty members, by exercising leadership styles and creative skills in managing The work of the faculty, which is the nucleus of education in any university, and the extent of the results of that deans of faculties achieve results through the exercise of a leadership style in achieving job satisfaction for the faculty members working for him in light of financial developments and alleviating the surrounding pressures that affected the faculty member in that Universities (Arabiyat, 2012).

\section{Terminology of Study}

Leadership behavior or leadership style is defined as the skills that can be learned and trained on, and resorting to them with the aim of influencing others through creativity in the field of work based on experiences and mental capabilities (Qattami and Abunaim, 2016).

The importance of the leadership style followed by the leader in knowing the most leadership styles is effective in achieving the goals of higher education institutions according to what he sees (AlMeshal, 2006). These patterns are:

A. Autocratic style: In this style, the leader is unique in setting policies and making decisions and forcing subordinates to implement his decisions.

B. Free style: In this style, the leader leaves his subordinates responsibility and freedom to act, so he does not participate with them in taking the decision, and each subordinate performs his work in the manner that suits him. In this paper, the democratic leadership style will be measured with the job satisfaction of faculty members.

The concept of job satisfaction includes the individual's attitudes toward important dimensions such as the organization, direct supervision, financial rewards and colleagues in the job and job design. It is not necessary that all of these trends are that one is positive or not positive. Changes in organization policy or job evaluation (Asali, 2009).

Al-Maliki (2007) defines him as a group of emotional feelings that one feels towards work, which he currently occupies, and these feelings may be negative or positive, and it expresses the extent of gratification that the individual perceives that he accomplishes from his work, and whenever the individual's perception that his work is achieving satisfaction Great for his needs, the more his feelings 
about this work are positive, that is, the more he is satisfied with his work, but the more the individual perceives that his work deprives him of this gratification, the more negative his feelings towards this work, that is, he is not satisfied with his work.

Innovation is bringing something differently from its past, and creativity begins from the first moment when an individual begins to think about his idea that did not exist before, and the creator is the owner of the creativity that no one preceded him to the inventive thing (Salem, 2014).

managerial of innovation is working on improving and reforming the plans, procedures, available materials, methods and goals, and constantly reviewing them to ensure the effectiveness and motivation of the work, and it can also be defined as the innovation of a modern methodology for work by optimizing the potential and resources available at the lowest costs and the fastest time possible (Al-Salimi, 2008 ).

Hence the problem of the study, which will be highlighted, has emerged to know the relationship of the leadership style practiced by the dean of the college in order to, achieve job satisfaction for a member of faculty in private universities in Jordan with the presence of a moderating variable (managerial of innovation).

The first objective: To study the relationship of the autocratic leadership style practiced by the dean of the faculty in private universities in Jordan and to achieve job satisfaction for faculty members in it with a moderating variable (managerial of innovation).

The second objective: To study the relationship of the free and leadership style practiced by the dean of the faculty in private universities in Jordan and to achieve job satisfaction for faculty members in it with a moderating variable (managerial of innovation).

\section{Theoretical Framework}

There are many reasons for adopting the causes of job satisfaction, the most important of which is that high job satisfaction leads to an increase in the level of ambition among workers in different institutions, and a decrease in the absence of workers in different professional institutions, and that individuals with high levels of job satisfaction are more satisfied with their free time Especially with their families, as well as more satisfied with life in general, and they are less vulnerable to the inconveniences and harassment of work, there is a close relationship between job satisfaction and production at work, whenever there is a high degree of satisfaction whenever it leads to increased production (Khazaleh, 2014).

Many literatures review have paid attention to the job satisfaction of members of any commercial or educational establishment. Al-Dais (2016) measured the degree of job satisfaction for faculty members at Sana'a University from their point of view, and the study variables were specialization and academic rank, and the researcher used the questionnaire as an instrument to collect data, and the study sample was composed of (4000) members of the faculty, and the results showed that The degree of job satisfaction was low, and in Al-Ajrafi study (2017), where job satisfaction was addressed by the heads of colleges departments at Shaqra University in Al-Dawami as a dependent variable and the effect of administrative empowerment on it, where the researcher used the survey descriptive methodology, as the questionnaire was used for the purpose of achieving the goal of the study, and the study proved There is a high and significant correlation between administrative empowerment and job satisfaction. Al-Naimat (2016) conducted a study aimed at knowing the role of school leadership in developing innovative skills for secondary school teachers. The researcher used a 
questionnaire for the purposes of data collection, and the study sample consisted of (59) teachers. The researcher used the descriptive methodology, and the results of the study indicated that the styles School leadership came with a medium degree. From here and from the above, the study hypotheses will be formulated as follows:

The first hypothesis: There is a negative relationship at $\alpha \leq 0.05$ between the autocratic leadership style and the job satisfaction of the faculty members in private universities in Jordan from the point of view of the faculty members in the presence of the moderating variable (managerial of innovation). The second hypothesis: There is a negative relationship at $\alpha \leq 0.05$ between the free leadership style and job satisfaction of faculty members in private universities in Jordan from the viewpoint of faculty members in the presence of the moderating variable (managerial of innovation).

\section{The Explaining Theory}

\section{Value Theory and Justice Theory}

"Edwin Locke" was the first to introduce the value theory of the year (1976), and it is considered one of the most important theories explaining job satisfaction. Satisfied with his work, first of all he determines the difference between what he needs and what he actually gets, and then determines the value or importance of the needs he wants.

As for the theory of justice by writer Adams, he returned 1965, and this theory explains job satisfaction on the main hypothesis that the degree of job satisfaction for an employee depends on the amount of justice he feels between the efforts he provides for his job.

\section{Methodology}

The descriptive methodology addresses the phenomena and events as actually presented in terms of features and shapes, and the factors affecting it. It studies the present phenomena and events by describing them, with all aspects and dimensions, and aims to extract solutions and determine the causes, the relationships that led to these phenomena and events, as well as the identification of relationships Together, and the external factors affecting them, to benefit from them in predicting the future of these events and phenomena. The most descriptive methodology is used in the social sciences according to its features so that it monitors and tracks phenomena accurately and in a quantitative and qualitative manner in a specific time period or for several periods of time, with the aim of reaching the reasons for the phenomena and factors causing the occurrence of a phenomenon, and then reaching the results that help in understanding Present and future prediction (Dishley, 2016).

The relational descriptive methodology is concerned with the study of the phenomenon as it exists in reality, and it is concerned as a methodology description, and it is expressed qualitatively or quantitatively. The qualitative expression describes the phenomenon and its characteristics, whereas the quantitative expression describes it numerically, and it also shows the amount or size of the phenomenon and the degree of its association with other phenomena (Nasser, 2013).

This study has developed a special questionnaire, in order to identify the effect of leadership behavior of deans of faculties in private universities on job satisfaction in the presence of the moderating variable (managerial of innovation) for faculty members from their viewpoint in those universities, and this study dealt with two types of leadership styles, namely the autocratic leadership style And 
INTERNATIONAL JOURNAL OF ACADEMIC RESEARCH IN BUSINESS AND SOCIAL SCIENCES

Vol. 10, No. 7, July, 2020, E-ISSN: 2222-6990 @ 2020 HRMARS

the free leadership style in order to, measure their relationship with job satisfaction, where the instrument consisted of three main axes:

The axis of leadership styles, and it contains two dimensions, the autocratic style and the free style. The axis of job satisfaction.

The questionnaire of the current study was presented to a number of 4 reviewers who are experienced and specialized in the field of administration and education in order to arbitrate the instrument to ensure its validity. This study was applied to the 346 faculty members in private universities in Jordan. The researcher distributed 390 questionnaires to the study sample, it was found that the number of unresponsive 20 members with a response rate of $94.87 \%$ and also that 24 questionnaires were not properly packed by the respondents. Thus, the total number of questionnaires valid for analysis is 346 (required sample).

\section{Questionnaire's Reliability}

The "Cronbach's Alpha" test was used. It measures the consistency of the respondents answers to all the questions on the scale. "Cronbach Alpha" can be interpreted as the coefficient of internal Reliability between answers, and the higher its value, the higher the degree of Reliability where the value is high if it is greater than (80\%) and medium if it is between (70\%-80\%) and low if it is less than (65\%) (Gujarati, 2004), it is clear from (Table. 1) that the values of coefficients ranged from weakness to strength, and this indicates that the study instrument was well diversified when taking the opinions of the respondents.

Table. 1: The Reliability Results

\begin{tabular}{|c|c|c|}
\hline section & $\begin{array}{l}\text { No. } \\
\text { Staments }\end{array}$ & Cronbach Alpha \\
\hline $\begin{array}{l}\text { A measure of (autocratic,free) leadership style for } \\
\text { deans faculty. }\end{array}$ & 21 & 0.814 \\
\hline Jop satisfaction measure for faculty members & 18 & 0.899 \\
\hline the moderating variable managerial of innovation). & 15 & 0.966 \\
\hline Total questionnaire questions. & 54 & 0.893 \\
\hline
\end{tabular}

The Results of The Study

1. Results related to the Descriptive Analysis (Autocratic, free, Jop satisfaction, Managerial of innovation).

The independent variable (democratic leadership style) with the presence of the moderating variable (managerial of innovation), and was studied with the dependent variable (job satisfaction).

According to the results shown in Table. 2, it shows the results of mean, standard deviations, maximam and minimim values, for a measure of (Autocratic,Free) leadership styles for faculty deans in private universities in Jordan. 
INTERNATIONAL JOURNAL OF ACADEMIC RESEARCH IN BUSINESS AND SOCIAL SCIENCES Vol. 10, No. 7, July, 2020, E-ISSN: 2222-6990 @ 2020 HRMARS

Table. 2: Descriptive Analysis (Autocratic,Free, Jop satisfaction, Managerial of innovation).

\begin{tabular}{|c|c|c|c|c|c|}
\hline section & $\begin{array}{l}\text { No. } \\
\text { Statment }\end{array}$ & $\min$ & Max & Mean & $\begin{array}{l}\text { Std. } \\
\text { Deviation }\end{array}$ \\
\hline $\begin{array}{l}\text { A measure of autocratic leadership style for } \\
\text { deans faculty. }\end{array}$ & 7 & 1 & 5 & 3.94 & 0.980 \\
\hline $\begin{array}{l}\text { A measure of free leadership style for deans } \\
\text { faculty. }\end{array}$ & 7 & 1 & 5 & 3.73 & 0.94 \\
\hline Jop satisfaction measure for faculty members. & 18 & 1 & 5 & 4.13 & 0.90 \\
\hline $\begin{array}{l}\text { The moderating variable (managerial of } \\
\text { innovation). }\end{array}$ & 15 & 1 & 5 & 4.19 & 0.965 \\
\hline
\end{tabular}

\section{Test of Normality}

The study used a test of normal distribution of all variables, where the values of Skewness and Kurtosis were used. The data are subject to normal distribution if the Skewness values are less than 3 and the Kurtosis values are less than 10. Table. 3 indicates the results of the normal distribution test for the study variables:

Table. 3: Test of Normality

\begin{tabular}{|l|l|l|l|l|}
\hline \multirow{2}{*}{ Axis } & \multicolumn{3}{|l|}{ Kurtosis } & Skewness \\
\cline { 2 - 5 } & $\begin{array}{l}\text { Statistical } \\
\text { value }\end{array}$ & $\begin{array}{l}\text { Random } \\
\text { error }\end{array}$ & $\begin{array}{l}\text { Statistical } \\
\text { value }\end{array}$ & $\begin{array}{l}\text { Random } \\
\text { error }\end{array}$ \\
\hline $\begin{array}{l}\text { Autocratic leadership } \\
\text { style }\end{array}$ & 0.337 & 0.355 & $0.502-$ & 0.179 \\
\hline Free leadership style & 0.659 & 0.355 & $0.543-$ & 0.179 \\
\hline Jop satisfaction & 0.215 & 0.355 & $0.615-$ & 0.179 \\
\hline $\begin{array}{l}\text { The moderating } \\
\text { variable (managerial } \\
\text { of innovation). }\end{array}$ & 0.690 & 0.355 & $0.566-$ & 0.179 \\
\hline
\end{tabular}

Table. 3 indicates that all Skewness values were less than 3 as the highest value $(-0.502)$ of the job satisfaction axis, while Kurtosis, all values were less than 10 . These results indicate that all study variables are safe from normal distribution problems.

\section{Hypothesis testing}

For hypothesis testing, a 3-step multiple regression analysis is used, where the criterion for accepting hypotheses will be as follows: The hypothesis is accepted if the value of the significance is more than 0.05 and will be rejected if the value of the significance is less than or equal to 0.05 . Table. 4 shows the results: 
INTERNATIONAL JOURNAL OF ACADEMIC RESEARCH IN BUSINESS AND SOCIAL SCIENCES Vol. 10, No. 7, July, 2020, E-ISSN: 2222-6990 @ 2020 HRMARS

\section{Table. 4: Hypothesis testing}

\begin{tabular}{l|l|l} 
variable & T & Sig. \\
\hline $\begin{array}{l}\text { Autocratic leadership style } \\
\text { with the moderating variable }\end{array}$ & $2.307-$ & 0.018 \\
\hline $\begin{array}{l}\text { Free leadership style with The } \\
\text { moderating variable }\end{array}$ & $2.916-$ & 0.011 \\
\hline $\mathrm{R}^{2}$ & 0.793 \\
\hline $\mathrm{R}^{2}$ Change & 0.075 \\
\hline $\mathrm{F}$ & 51.057
\end{tabular}

Firstly: The calculated value of T was: (2.307-) and with a statistical significance of (0.018), which indicates that there is a negative relationship with statistically significant at the level of significance $\mathbf{0 . 0 5}$ for the autocratic leadership style of faculty deans and between job satisfaction through the presence of the moderating variable (managerial of innovation) in Jordanian universities, and the study sees that the higher the autocratic leadership styles in light of the managerial of innovation of faculty deans, job satisfaction will decrease. And accordingly accept that states:

First hypothesis: "There is a negative relationship at $\alpha \leq 0.05$ between the autocratic leadership style and the job satisfaction of the faculty members in private universities in Jordan from the point of view of the faculty members in the presence of the moderating variable (managerial of innovation)". Secondly: The calculated value of $\mathbf{T}$ was (2.916-) with a statistical significance of (0.011), which indicates that there is a negative relationship of statistical significance at the significance of 0.05 for the free leadership style of the deans of faculties and between job satisfaction through the presence of the moderating variable (managerial of innovation) in private universities in Jordan, and the study sees that the higher the leadership styles free in light of the managerial of innovation of faculty deans, job satisfaction will decrease. And accordingly accept that states:

Second hypothesis : "There is a negative relationship at $\alpha \leq 0.05$ between the free leadership style and the job satisfaction of the faculty members in private universities in Jordan from the point of view of the faculty members in the presence of the moderating variable (managerial of innovation)".

\section{Conclusions and Recommendations}

Conclusions and recommendations

Through the above and after conducting the analysis using methods of statistical analysis of the study sample, the following recommendations and suggestions were reached:

a. Avoid working with the autocratic leadership style and the free leadership style, which achieved a negative impact on the job satisfaction of faculty members in private universities in Jordan by practicing these leadership styles by deans of faculties.

b. Achieve job satisfaction for faculty members at universities by searching for other leadership methods that achieve their aspirations to accomplish what is required of them to raise the level of education and innovation.

\section{Contribution of the Study}

The importance of this study lies in contributing to:

1. Give the concept of job satisfaction a great importance and make it a priority for faculties deans in those universities.

2. Providing libraries with knowledge by identifying leadership styles that affect job satisfaction. 
INTERNATIONAL JOURNAL OF ACADEMIC RESEARCH IN BUSINESS AND SOCIAL SCIENCES

Vol. 10, No. 7, July, 2020, E-ISSN: 2222-6990 @ 2020 HRMARS

3. A reference for researchers and those interested and provides them with the means necessary for further studies.

4. It helps decision makers to improve, develop and raise the level of job satisfaction through adopting the most effective leadership style and avoiding traditional leadership styles that negatively affect the achievement of job satisfaction.

\section{Acknowledgement}

Many thanks to those who provided assistance in completing this study, especially Dr. Najihah Abd Wahid.

\section{References}

Abu-Nasser, Fathi, M. A. (2013). Constituents and practices of managerial of innovation from the viewpoint of educational leaders of talented student's programs in the Eastern Organization in the Kingdom of Saudi Arabia - King Faisal University - Saudi Arabia.

Al-Maliki, A. (2007). Job satisfaction and mental health level for school counselors in Makkah AlMukarramah. Saudi Arabia. Umm Al Qura University.

Al-Meshal, N. H. (2006). Leadership styles among principals in the primary stage for girls in Riyadh and their relationship to the job satisfaction of female teachers. unpublished Master Thesis, Riyadh, Imam Muhammad bin Saud Islamic University.

Al-Mikhlafi, M. V. (2009). Educational administrative leadership in higher education institutions, $\left(1^{\text {st }}\right.$ edition), amman: Zahran Publishing House.

Al-Nuaimat, M. M. (2016). The role of school leadership in developing creativity among secondary school teachers in raising the Kasbah of Oman from the teachers 'point of view. The eleventh conference of the Faculty of Physical Education. University of Jordan, and the third of the College of Arab Physical Education, integrative in sports sciences.

Asali, N. (2009). Conflict Management and its Impact on Job Satisfaction of Workers A Case Study of Al-Hudna Mills Corporation - M'Sila Province. Master Thesis, University of Alger

Al-Salimi, M. M. (2008). Administrative creativity (concept, importance, principles, motivations), Riyadh: the educational culture. Riyadh.

Arabiyat, B. (2012). The prevailing styles of educational leadership among the heads of academic departments at Al-Balqa Applied University and its impact on the job performance of faculty members (College of Technology Engineering Case Study). Journal of the Islamic University of Educational and Psychological Studies, 20(2).

Bryah, M. A., and Moussaoui, Y. (2016). The effect of job satisfaction on the performance of human resources. A case study of the public hospital hospital in Maghnia. Master Thesis, Abi Bakr University Belkaid Tlemcen.

Dishley, K. (2016). Scientific Research Methodology, Directorate of Books and University Publications, Publications.

Gujarati, D. N., \& Porter, D. C. (2004). Basic econometrics (ed.). Mc Graw-Hill. Irwin, a business.

Khazaleh, M. (2014). Extent of job satisfaction with King Faisal University employees in the Kingdom of Saudi Arabia, Al-Manara, 20(1).

Qattami, Y., and Abu-Naim, M. (2016). Self-realization and future leadership, $1^{\text {st }}$ edition, Debono Center for Teaching Thinking. 
INTERNATIONAL JOURNAL OF ACADEMIC RESEARCH IN BUSINESS AND SOCIAL SCIENCES

Vol. 10, No. 7, July, 2020, E-ISSN: 2222-6990 @ 2020 HRMARS

Salem, A. G. (2014). Creativity and how to discover and develop creative ideas, Alloka Network. Hama University.

Zakaria, A. M. A. (2017). The degree of satisfaction of faculty members with the performance of scientific councils at the University of Najran, International Specialized Educational Journal, 6(10). 